\title{
Development of Science Learning Tools to Train Critical Thinking Skills of Junior High School Students in Static Electricity Topics
}

Mutiara Havina Putri", Suryajaya, Yudha Irhasyuarna

Master Program of Natural Sciences Teaching, Lambung Mangkurat University, Banjarmasin, Indonesia

DOI: 1 10.36348/jaep.2020.v04i11.004 | Received: 29.10.2020 | Accepted: 11.11 .2020 | Published: 17.11 .2020

*Corresponding author: Mutiara Havina Putri

\section{Abstract}

This study aims to evaluate the practicality, validity, and effectiveness of the static electricity subject matter learning tool for junior high school students. Learning tools include syllabus, lesson plans, teaching materials, student worksheet, and assessment sheets. The research model used is the Tessmer development model which consists of five steps, namely as follows: 1) self-evaluation; 2) expert opinion (expert review); 3) Individual trial (one to one); 4) small group trials; and 5) field test. The data analysis technique used in this research is quantitative analysis which includes data analysis on the validity of learning tools, data analysis on the practicality of learning tools, and data analysis on the effectiveness of learning tools. This type of research is development research. The research was conducted at SMP Negeri 2 Bati-Bati. The research subjects consisted of the subject of validation of five experts, the subject of individual trials of three students, the small group trial consisting of five students and the field test consisting of 27 students. The results showed that the learning tools developed were valid, practical and effective. Valid based on the results of tool validation by the validator including syllabus, lesson plans, teaching materials, worksheets, and LKPD assessment sheets which are categorized as valid and readability test of teaching materials and worksheets by students who are categorized as good. Practical based on the activities of teachers and students who are categorized as good from the lesson plan implementation sheet. Effective based on the results of worksheets that show an increasing trend in indicators adapted from Watson-Glaser's critical thinking skills.

Keywords: Learning tool development, discovery learning, critical thinking skills.

Copyright (0) 2020 The Author(s): This is an open-access article distributed under the terms of the Creative Commons Attribution 4.0 International License (CC BY-NC 4.0) which permits unrestricted use, distribution, and reproduction in any medium for non-commercial use provided the original author and source are credited.

\section{INTRODUCTION}

Currently, Natural Science Education (IPA) has not been much oriented towards habituation and enhancement of higher order thinking skills. In fact, through science learning, students are expected to be able to practice higher order thinking skills. But in fact, students only absorb information passively and then remember it while taking the test [1]. Learning like this results in students not gaining experience to develop their thinking skills, even though the demands in the field of education are getting higher every year. One of the skills that is indispensable is the ability to think at a higher level in the face of globalization in line with the development of science and technology. The challenge now is to train students to think at high levels, critical thinking skills are one of the higher order thinking skills [2]. Based on the results of the PISA survey from 2009 to 2018, Indonesia's ranking has always decreased and indicates the weak ability of Indonesian students in the field of science. The results of this study can be used as a reference regarding the level of scientific ability of
Indonesian children compared to other countries. This is a challenge faced by Indonesia and other developing countries to be able to compete in need of human resources who have the ability to think effectively, therefore critical thinking is a valuable resource in teaching [3].

The ability to think in science is closely related to how to find out and understand the universe systematically, which contains concepts, theories or formulas that must be understood in depth. Thus, students are required to be able to think critically in building knowledge with an active role in the learning process. However, in fact, based on the results of observations that have been made at SMP Negeri 2 Bati-Bati through interviews with science educators and observations in the learning process, it shows that the learning process is seen only as a transfer of knowledge, learning becomes less attractive as a result of not developing the ability to ask and reason. The evaluation questions given have not been oriented to 
developing students' critical thinking skills, so that students are not encouraged to develop their thinking skills. This results in low critical thinking skills of students.

Lasmawan [4] identifies several educational problems, namely (1) education emphasizes more on cognitive aspects with as much knowledge orientation orientation and ignores the development of affective and connective aspects, (2) education does not provide the development of process skills, critical thinking skills, and creative, (3) education does not provide real experience through an integrated curriculum and learning approach. Educational improvement through curriculum development according to the Supervision of the Ministry of Education (MOE) of Taiwanese educational institutions, covering major themes such as scientific literacy, process skills, scientific attitudes, thinking skills, and application of science [5]. In general, the curriculum is nothing but a set of learning which is a means of supporting the success of learning and makes the learning process more effective. Planning a good learning tool has an impact on the implementation of successful learning. The potential of students can also be realized in education through the development of learning tools. This is in accordance with the main goals of education, namely developing individual talents, realizing creative and innovative potential, achieving goals and personal responsibility for social life in society.

The importance of students having critical thinking skills because these skills allow students to be able to analyze and evaluate information in determining reliable information so that it can be used as a basis for drawing valid conclusions. According to Marie and Emmanuelle [6] the ability to think is not innate possessed by students, but thinking skills can be learned and require learning. There are five indicators of critical thinking derived from critical activities according to Ennis [7], namely (1) being able to formulate the main problems; (2) able to reveal the facts needed to solve a problem; (3) able to choose logical, relevant, and accurate arguments; (4) able to detect bias based on different viewpoints; and (5) able to determine the consequences of a statement taken as a decision. These indicators vary for each individual depending on the exercises that are often done to develop them. Educators must be able to become facilitators in the learning process, not only focusing on educational activities but also on students' thinking skills which aim to improve critical thinking, creative thinking and argumentation skills [8].

Based on the explanation above, it is necessary to make efforts in the learning process to be able to practice critical thinking skills of students, one of which is by choosing the right and more student-centered learning approach. One such learning model is the discovery learning model where in this model students learn to discover and discover concepts independently [9]. Discovery learning models require students to be active, creative, and innovative to involve process skills knowledge in building concepts, laws or principles, and to involve potential cognitive processes in stimulating intellectual development [10]. This reveals that the discovery learning model fits the scientific approach, where the end result is expected to develop scientific process skills so as to train students critical thinking skills.

\section{RESEARCH METHODS}

This type of research is a development research using the Tessmer development design. According to Akker [11] Tessmer's development model consists of five steps, namely as follows: 1) self-evaluation; 2) expert opinion (expert review); 3) Individual trial (one to one); 4) small group trials; and 5) field test. The research subjects were class 9D students at SMP Negeri 2 Bati-Bati. Individual trials using a sample of three students, small group trials using a sample of five students, and field trials using subjects totaling 27 students. This research was conducted from August to December, 2019. Data collection techniques were carried out through observation, documentation, and tests. Observation is used to determine the practicality and effectiveness of the learning tools being developed. The written test is used to assess critical thinking skills. Documentation is done to record the learning process that occurs in accordance with the learning tools developed. The data analysis technique used in this research is quantitative analysis which includes data analysis on the validity of learning tools, data analysis on the practicality of learning tools, and data analysis on the effectiveness of learning tools.

\section{RESULTS AND DISCUSSION}

Before being used in the field, the learning tool must first be tested. The trial activity aims to produce learning tools that are suitable for use in learning, namely learning tools that meet validity, practicality, and effectiveness.

\section{The Validity of Learning Tools}

The validity of the measured learning tool is the validity of the content based on the results of the evaluation by the validator. One of the main criteria for determining whether a learning tool can be used or not is the result of expert or practitioner validation. Based on the validation test by experts and practitioners, the tool has met the validity element with the assessment obtained is valid. The validity of learning tools is not only obtained from expert opinion (expert review), but also based on input and suggestions from students in the one-to-one test. This test was conducted to determine the readability of students on teaching materials and LKPD. The one-to-one test used a questionnaire given to 3 students of SMP Negeri 2 BatiBati class 9D. Based on the results of the students' 
assessment above, it can be said that the teaching material is categorized as good and can be used for the next stage with a revision of the material description, namely the addition of appropriate images and illustrations that need to be given information so that the teaching material and worksheets become easier to understand.

According to Van den Akker et al., [11], learning tools are said to be valid in terms of content and construct. (1) Content validation, that is, if the product is said to be developed it has an adequate theoretical basis; (2) Construct validation, namely if all product components are related to one another consistently [12]. In addition, according to Suherman in
Hobri [13], a tool is said to be valid if the tool is able to measure what is being measured.

\section{Practical Learning Tools}

The practicality of the developed learning tools is measured against the implementation of the learning process, both in the form of teacher activities and student activities assessed by observers. According to Nieveen [14], the practical aspect is a criterion for the quality of a learning tool in terms of the ease with which teachers and students use the developed learning tools. The results of field tests on practicality seen from the implementation of the lesson plans in the form of teacher activities in class 9B are presented in Table-1 below.

Table-1: Results of Teacher Activities in Field Tests

\begin{tabular}{|c|c|c|c|c|c|c|c|c|}
\hline \multirow[t]{2}{*}{ No } & \multirow[t]{2}{*}{ Learning Activities } & \multicolumn{5}{|c|}{ Average Score of Each Meeting (\%) } & \multirow[t]{2}{*}{ Average (\%) } & \multirow[t]{2}{*}{ Category } \\
\hline & & 1 & 2 & 3 & 4 & 5 & & \\
\hline 1. & Opening & 89.29 & 89.29 & 92.86 & 92.86 & 96.43 & 92.14 & Very good \\
\hline 2. & Main & 80.00 & 80.00 & 86.67 & 85.00 & 90.00 & 84.33 & Well \\
\hline 3. & Closing & 81.25 & 87.5 & 93.75 & 87.5 & 93.75 & 88.75 & Very good \\
\hline
\end{tabular}

Table-1 explains that the learning process in the opening and closing activities of the teacher's activities is categorized as very good and in the main activity is categorized as good. Teacher activity in the preliminary stage always increases in each meeting. However, at the core and closing stages there was a decrease in the fourth meeting, this was due to the lack of literacy and early knowledge of students regarding the discussion of nerve cells which caused the teacher to take longer to guide students in completing worksheets, thus interfering with other activities. However, the teacher is able to carry out learning activities using well-developed tools, so it can be said that the learning tools developed by researchers can be applied to the general classroom learning process. Suryani [15], stated that the implementation of the learning process with the discovery learning model from the user (lecturer) perspective $87.88 \%$ was carried out very well while from the student side, namely $83.33 \%$ was also carried out well.

Furthermore, the activities of class 9B students to see the implementation of learning are presented in Table-2 below.

Table-2: Results of Student Activities in Field Tests

\begin{tabular}{|c|c|c|c|c|c|c|c|c|}
\hline \multirow[t]{2}{*}{ No } & \multirow[t]{2}{*}{ Learning Activities } & \multicolumn{5}{|c|}{ Average Score of Each Meeting (\%) } & \multirow[t]{2}{*}{ Average (\%) } & \multirow[t]{2}{*}{ Category } \\
\hline & & 1 & 2 & 3 & 4 & 5 & & \\
\hline 1. & Opening & 83.33 & 91.67 & 91.67 & 87.50 & 95.83 & 90.00 & Very good \\
\hline 2. & Main & 75.00 & 82.14 & 91.07 & 75.00 & 87.50 & 82.14 & Well \\
\hline 3. & Closing & 83.33 & 83.33 & 91.67 & 83.33 & 91.67 & 86.67 & Very good \\
\hline
\end{tabular}

Based on Table-2, we can see that the activity of students in the field test showed good results, even though there was one decrease in student activity, namely at the fourth meeting, where it was because the discussion about nerve cells was difficult for students to understand so it took a long time to gather information in assessing a statement. Suardi in Khadija [16] states that as a consequence that students are the center of learning, student activity is an absolute requirement for teaching-learning interactions to take place in addition to teacher activities who act as guides. The activities of students during the five meetings seen from the average are high, this shows that there is student interest in learning activities with interactions between teachers and students and fellow students so that learning can take place smoothly. This is in line with research conducted by Fernanda et al., [17] which states that the relationship between social interaction and learning outcomes is at a degree of closeness in the medium category. In addition, research conducted by Alhassan [18] also shows that the interaction of students in learning has a positive influence between social interaction and motivation in learning. In general, both teacher activities and student activities seen from the implementation of the lesson plans are in good categories and it can be said that learning tools are practical and easy to implement. According to Plomp [19] a learning tool is said to be practical if it can be used easily by teachers and students in learning.

\section{Effectiveness of Learning Tools}

The learning tool developed will be categorized as effective if the tool is able to achieve research objectives or has added value or added value 
from existing learning tools. The critical thinking tool developed uses a discovery learning model and is an adaptation of Watson-Glaser's critical thinking instrument. The researcher adapted the five indicators by conducting simple experiments to assess a conclusion based on logical data.

The first indicator of critical thinking is inference which is the activity of students to assess and analyze the true or false statements given, namely in the form of conclusions. The second indicator is the recognition of assumptions, at this stage students identify relevant statements or problems, the teacher helps guide students in critical analogies and descriptions from various points of view. The third indicator is deduction which provides initial conclusions. The fourth indicator is an interpretation which requires students to assess the evidence or information provided to decide whether conclusions based on data are guaranteed to be true. The fifth indicator is the evaluation of the argument, in this stage students evaluate the strength and relevance of the argument with respect to a particular question or problem. The results of the critical thinking skills of the five indicators on the field test for five meetings can be seen in Figure-1 below.

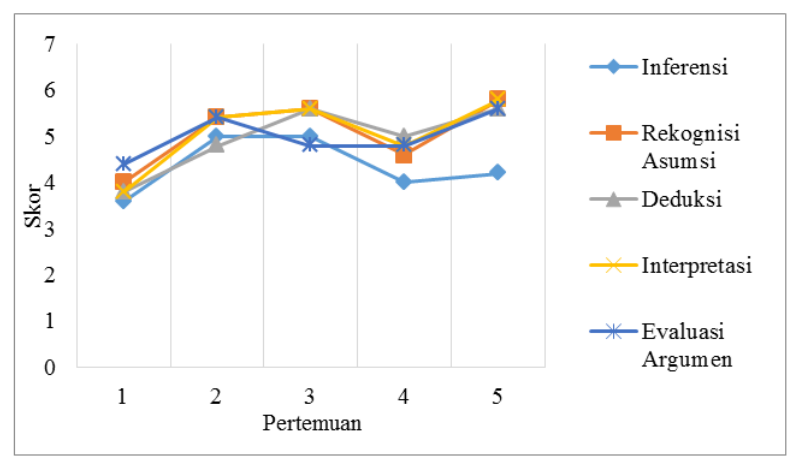

Fig-1: Results of Field Test Critical Thinking Skills

Based on the assessment of critical thinking skills carried out during the field test on the inference indicator, there was a downward trend at the fourth meeting of most groups. There is a possibility that students have difficulty understanding the questions on this indicator, especially in the fourth LKPD. Changes that are not too significant in the inference indicator are because students often determine that the statements or conclusions given are always correct, but ignore logical data information or not. This problem can be overcome by doing perceptions and organization at the beginning of learning activities by emphasizing the relationship of learning with the environment in everyday life, so that students have good knowledge readiness for learning that will take place supported by their literacy. The results of the assessment of the assumption recognition indicators showed an increasing trend in most groups, and there were even four groups that received maximum scores. Students are relatively easy to judge a logical argument by providing reasons and correct conclusions. The deduction indicators obtained good and varied results. All groups experienced an increasing trend. The ability of students to draw conclusions based on the information provided can be said to be good, although it still needs to be improved.

The assessment results of the interpretation indicators experienced an increasing trend for all groups. This increase in skills is marked by the obedience of students in carrying out instructions, students are able to interpret a conclusion based on the information provided and ignore general knowledge but must remain logical. The results of critical thinking skills on the evaluation indicators of field test arguments can be said to be good. The results of the evaluation of the students' argument evaluation indicators also experienced an increasing trend in several groups. This is indicated by the fact that most groups of students have been able to provide the right reasons, indicating that students can distinguish arguments that are directly or indirectly related to the content of the conclusion.

The learning results in the field test showed that of the 27 students who had not met the completeness of the minimum score in science subjects there were 10 students while those who had completed with a value of $\geq 70$ were 17 students. Overall the students' scores were good, more than half of the students in class 9B got complete learning results (had mastered the lesson), so it was said that the learning tools developed could be applied during the learning process. Based on the results of overall observations in the field test, it shows good results. The use of developed learning tools is considered to be running well. Teachers and students are considered quite comfortable in using tools which require active and intense communication in its implementation. As for practicing critical thinking skills, there is a fairly good improvement, this can be seen from the results of critical thinking of students who are not at the minimum value and can indicate that the critical thinking process can be assessed through written reasons. These results illustrate that the developed critical thinking learning tools can be used in the field as a whole in real classrooms or in other words, the tools developed can be categorized as effective. Zaini and Supiati [20] state that students' critical thinking skills seen in learning are one of the effectiveness of a learning tool.

\section{CONCLUSION}

Based on the results of research on the development of learning tools, it is concluded that the learning tools are said to be valid based on the results of validating the tools by the validator including syllabus, lesson plans, teaching materials, LKPD, LP LKPD which are categorized as valid and the test of teaching material legibility and LKPD by students who are categorized as good. The learning tool is said to be practical based on the activities of teachers and students 
who are categorized as good from the lesson plan implementation sheet. The learning tools are said to be effective based on the results of the LKPD which show an increasing trend in indicators adapted from WatsonGlaser's critical thinking skills [21].

\section{REFERENCES}

1. Bassham, G., Irwin, W., Nardone, H., \& Wallace, J. M. (2010). Critical Thinking: A Student Introduction. $4^{\text {th }}$. Mc Graw-Hill Company, Inc. http://s3.amazo

naws.com/engrademyfiles/4008228113384505/Stu dents_Guide_to_Critical_Thinking.pdf.

2. Adnyana, G. P. (2012). Keterampilan Berpikir Kritis dan Pemahaman Konsep Siswa Pada Model Siklus Belajar Hipotetis Deduktif. Jurnal Pendidikan dan Pengajaran. 45(3),201-9. https://ejournal.undiksha.ac.id/index.php /JPP/article/view/1833/1603.

3. Leandro da Silva, A., \& Amanda, H. R. F. (2011). Critical Thinking: Its Relevance for Education in A Shifting Society. Revista de Psicología. 29(1) 2011.

4. Lasmawan, W. (2004). Pengembangan model pendidikan berdemokrasi dalam pembelajaran PPKn di Sekolah Dasar. Laporan Penelitian.

5. Shu-Nu, C., \& Mei-Hung, C. (2005). The Development of Authentic Assessments to Investigate Ninth Graders' Scientific Literacy: In The Case of Scientific Cognition Concerning The Concepts of Chemistry and Physics. International Journal of Science and Mathematics Education. 10(3). 117-140.

6. Marie, F. D., \& Emmanuelle, A. (2011). Philosophy, Critical Thinking and Philosophy for Children. Educational Philosophy and Theory. 43(5).

7. Ennis, R. (1998). Critical Thinking. Teaching Philosophy, 14(1), 5-24. http://doi.org/10.1016/B978-0-12-3750389.00057-1.

8. Barak, M., \& Dori, Yehudit, J. (2009). Enhancing Higher Order Thinking Skills Among Inservice Science Teachers Via Embedded Assessment. Department of Education in Technology and Science, Technion, Israel Institute of Technology, 32000 Haifa, Israel. J Sci Teacher Educ (2009). 20: 459-474. DOI 10.1007/s10972-009-9141-z. Springer Science Business Media.

9. Khabibah, E. N. (2017). The Effectiveness of Module Based on Discovery Learning to Increase Generic Science Skills. Journal of Education and
Learning. 11(2):146-153. http://doi.org/10.11591/edulearn.v11i2.6076.

10. Arianda, N. (2018). The Effects of Discovery Learning Model Nuanced Science Literacy Towards Students' Competence in Learning Natural Science. International Journal of Progressive Sciences and Technologies (IJPSAT) Vol. 8 (1). ISSN: 2509-0119. http://ijpsat.ijshtjournals.org.

11. Akker, Jan Van den. (2007). An Introduction to Educational Design Research. Proceedings of The Seminar Conducted at The East China Normal University, Shanghai (PR China), November 2326, 2007. London: Routledge.

12. Hafiz, M. (2013). Research and Development: Penelitian di Bidang Pendidikan yang Inovatif, Produktif dan Bermakna. Padang. Vol. 16 (1). http://ecampus.iainbatusangkar.ac.id.

13. Hobri. (2010). Metodologi Penelitian Pengembangan Aplikasi Pada Penelitian Pendidikan Matematika. Jember: Pena Salsabila.

14. Nieveen, N. (1999). Prototyping to Reach Product Quality. Jan Van den Akker, Robert Maribe Braneh, Ken Gustafson, and Tjeerd Plomp (Ed), London: Kluwer Academic Plubishers.

15. Suryani, H. (2016). Pengembangan Perangkat Pembelajaran Disain Busana Berbasis Discovery Learning dan Peningkatan Kreativitas Mahasiswa. Jurnal MEKOM (Media Komunikasi Pendidikan Kejuruan). 3(2), 145-151.

16. Khadija. (2016). Belajar dan Pembelajaran. Bandung: Citapustaka Media.

17. Fernanda, M., Sano, A., \& Nurfarhanah. (2012). Hubungan Antara Kemampuan Berinteraksi Sosial dengan Hasil Belajar. Jurnal Ilmiah Konseling. 1(1), 1-8.

18. Alhassan, J. (2015). Student Social Interactions and Learning in A Multicultural School. International Journal of Research in Humanities and Social Studies. 2(1):2394-6288.

19. Plomp, T., \& Nieveen, N. (2007). An Introduction to Educational Design Research. Proceedings of The Seminar Conducted at The East China Normal dan University. Shanghai (PR China), November 23-26.

20. Zaini, M., \& Supiati. (2017). Developing Learning Device on Environment Pollution Topic in Senior High School. Article number 31887-TSS. The Social Sciences, Medwell Journal Scientific Research Publishing Company (in press).

21. Watson, G., \& Glaser, E. M. (2008). WatsonGlaser Critical Thinking Appraisal Short Form Manual. Pearson Educion, Inc., or its affilie(s). United Stes of America. 